\title{
Potential benefits and toxicity of nanoselenium and nitric oxide in peppermint
}

\author{
Hossein NAZERIEH ${ }^{1}$, Zahra Oraghi ARDEBILI ${ }^{1 *}$, Alireza IRANBAKHSH ${ }^{2}$
}

Received January 13, 2018; accepted May 04, 2018.

Delo je prispelo 13. januarja 2018, sprejeto 04. maja 2018.

\begin{abstract}
Taking account of nano-compounds and biofortification, this research was conducted to evaluate peppermint (Mentha $x$ piperita L.) responses to nano-selenium (nSe; 0, 2, and $20 \mathrm{mg} \mathrm{l}^{-1}$ ) and/or nitric oxide (NO; 0 and $8 \mathrm{mg} \mathrm{l}^{-1}$ ). Significant increases in leaf length, and area, and shoot fresh mass were enhanced by the low level of nSe and/or NO, contrasted with the high dose. The inhibitory effects of the high dose of nSe on the growth-related characteristics were significantly mitigated by NO. The adverse impact of nSe20 on chlorophyll concentration was alleviated by NO. The individual and combined treatments of $\mathrm{nSe} 2$ led to the significant inductions in the activities of nitrate reductase and peroxidase, whereas nSe20 inhibited. The proline contents in the nSe and/or NOtreated plants were higher than in the control. The nSe and/or NO provoked stimulation in activities of phenylalanine ammonia lyase enzyme. The foliar applications of nSe and/or NO triggered the accumulations of soluble phenols. Interestingly, the toxicity of nSe at the high dose led to the severe cell destruction in the cortex layer of the basal stem, which was partially alleviated by NO. The simultaneous applications of these supplements may consider as an alternative strategy for fortifying and improving plant protection, regarding sustainable agriculture.
\end{abstract}

Key words: biofortification; elicitor; metal-based nanoparticle; Mentha x piperita; nitrate reductase; proline; selenium

\author{
IZVLEČEK \\ POTENCIALNE KORISTI IN STRUPENOST \\ NANOSELENA IN DUŠIKOVEGA OKSIDA PRI \\ POPROVI METI
}

Raziskava je bila izvedena za ovrednostenje odziva poprove mete (Mentha $x$ piperita L.) na nano selen (nSe; 0,2 , in $20 \mathrm{mg} \mathrm{l}^{-1}$ ) in/ali dušikov oksid (NO; 0 in $8 \mathrm{mg} \mathrm{l}^{-1}$ ). Značilno povečanje dolžine in površine listov in sveže mase poganjkov je bilo vzpodbujeno $\mathrm{z}$ majhnimi količinami nSe in/ali NO, nasprotno od učinkov velikih količin. Zaviralni učinki velikih koncentracij nSe na $\mathrm{z}$ rastjo povezane parametre so bili značilno zmanjšani z dodatkom NO. Negativni vpliv nSe20 na koncentracijo klorofila je bil ublažen $z$ NO. Posamično in kombinirano obravnavanje $\mathrm{z} n \mathrm{nSe} 2$ je vodilo $\mathrm{k}$ značilnem povečanju $\mathrm{v}$ aktivnosti nitrat reduktaze in peroksidaze, medtem ko jo je tretiranje $\mathrm{z}$ nSe20 zavrlo. Vsebnost prolina je bila $\mathrm{v} z \mathrm{nSe}$ in/ali $\mathrm{NO}$ obravnavanih rastlinah večja kot $\mathrm{v}$ kontroli. Obravnavanje z nSe in/ali NO je povečalo aktivnost fenilalanin ammonium liaze. Foliarno dodajanje nSe in/ali NO je vzpodbudilo kopičenje topnih fenolov. Toksičnost nSe je pri velikih dozah vodila $\mathrm{k}$ izrazitim razgradnjam celic $\mathrm{v}$ plasteh primarne skorje bazalnega dela stebla, kar je bilo delno oblaženo z dodatki NO. Hkratno uporabo teh dveh dodatkov lahko imamo kot alternativno strategijo za okrepitev in izboljšanje zaščite rastlin pri trajnostnem kmetovanju.

Ključne besede: biofortifikacija; elicitor; nano delci kovin; Mentha x piperita; nitrat reduktaza; prolin; selen

\section{INTRODUCTION}

Selenium (Se) is characterized as an essential trace mineral nutrient for many microorganisms, animals, and humans but it is not classified as an essential element for plants, despite its beneficial effects on the growth and physiology at low doses (Kaur and Nayyar, 2015). Awareness and concern about the Se significance to the human health issues are worldwide growing (Liu et al., 2017). In soil condition, selenite and selenate are the main sources of Se and may be efficiently uptake by plants. These mentioned forms of Se are mainly utilized to fortify different plants in the field production (Liu et al., 2017). Contrasted with many other living organisms, $\mathrm{Se}$ is not considered as an essential nutrient for plants. Otherwise, it seems to be a benefit for many plants, especially hyper-accumulators (El-Ramady et al., 2016). Thus, the functional significance of Se may lead to

\footnotetext{
1 Department of Biology, Garmsar Branch, Islamic Azad University, Garmsar, Iran, corresponding author: Zahraoraghi@yahoo.com

2 Department of Biology, Science and Research Branch, Islamic Azad University, Tehran, Iran
} 
enhance plant growth, modify cellular physiology, and/or improve plant resistance to abiotic and biotic stress conditions (Ardebili et al., 2014; Ardebili et al., 2015; El-Ramady et al., 2016).

Nitric oxide (NO) is known as a vital reactive nitrogen specie, a bioactive multi-task signaling molecule, and an elicitor of an array of signaling pathways by which regulates various aspect of plant development, physiology and defense responses (Gupta et al., 2011; Mur et al., 2013; Zhao et al., 2016). It is implicated in the control process of meristem cells (Sanz et al., 2014). There is evidence that NO may change auxin sensitivity and affects meristem cell activity (Sanz et al., 2014). NO, mainly via nitrosylation, can affect the activity of various proteins and play the role as a $\mathrm{Ca}^{2+}$-mobilizing intracellular messenger (Courtois et al., 2008). The application of sodium nitroprusside (SNP) as an exogenous NO donor is a most widely effective method to supplement plants with NO.

As nanotechnology science and technology is rapidly developing, the concerns about its benefits and toxicity on the environment are growing (Asgari-Targhi et al., 2018). Nano-forms possess unique physicochemical characteristics by which triggering especial responses different from their bulk type (Asgari-Targhi et al., 2018). Plants are considered as a key component for nanoparticle transport and bio-accumulation into the food chains (Tripathi et al., 2017). Therefore, various studies in different plant species are needed to elucidate the potential benefits and phytotoxicity of the nanoparticles, especially trace elements.

Some evidence provides data on NO-mediated alleviation toxicity signs of heavy metals, while little is known about NO-mediated mitigation of heavy metal stress and nanoparticle toxicity in plants (Tripathi et al., 2017). The Se nano-particles (nSe) with different characteristics of shape and size may be synthesized from Se salts especially selenates and selenite using reducing agents (Husen and Siddiqi, 2014). Moreover, there is evidence that the endogenous NO status at different developmental stages was altered by selenite treatment in Arabidopsis plants, mainly in a concentration and time-dependent manners (Lehotai et al., 2011).

On the basis of our knowledge, there is no research on the application of nSe on the plant growth, anatomy, and physiology. Also, as human body may intake Se from plants (White, 2015), finding an effective ecofriendly procedure for bio-fortifying, improving the defense-related system, and triggering secondary metabolism of medicinal plants, as well as introducing its toxicity range and signs are of critical importance. However, there is no report on the simultaneous application of $\mathrm{NO}$ and $\mathrm{nSe}$.

Peppermint (Mentha $x$ piperita L.) is an important economic, medicinal, and aromatic plant. Its leaves (as a spice) and vital secondary metabolites with the various critical antimicrobial, antioxidant and cytotoxic activities are widely utilized in the food and pharmaceutical-related industries (Çoban \& Baydar, 2016). It is well known that growth, physiology, and secondary metabolism in the medicinal plants is strongly affected by the different physicochemical and environmental factors. It is obvious that various researches are required to elucidate the plant responses to these factors and clarify the exact involved mechanisms. These findings may be helpful to improve our knowledge and agro-technologies, thereby developing new alternative strategies to improve plant growth, yield, and protection regarding sustainable agriculture and environmental issues. Therefore, regarding the above-highlighted significance of $\mathrm{Se}$, nanoparticle, NO, and peppermint the main objectives of the current research were to clarify the key physiological and anatomical mechanisms involved in the peppermint responses to the foliar applications of $\mathrm{nSe}$ and/or NO at different doses, for the first time.

\section{MATERIALS AND METHODS}

\subsection{Materials and treatments}

The applied nSe was purchased from the reliable company (NanoSany Corporation, Iranian Nanomaterials Pioneers Company; Mashhad City, Khorasan Province, Iran). Its characteristics were as follows: CAS\#: 7446-08-4; high purity: $99.95 \%$, APS: 10-45 nm; morphology: near spherical; true density: $3.89 \mathrm{~g} \mathrm{~cm}^{-3}$. The purchased nSe product was the stock solution of $1000 \mathrm{mg} \mathrm{1}^{-1}$ containing $0.1 \%$ polyvinylpyrrolidone (PVP) as stabilizer and thus, there is no need to a sonication protocol. Also, TEM image of
nSe is represented in Figure 1, showing the morphology and size of the nanoparticle. The supplied nSe was the stock solution of $1000 \mathrm{mg} \mathrm{l}^{-1}$, containing $0.1 \%$ polyvinylpyrrolidone (PVP) as a stabilizer and thus, there is no need to sonication protocol. SNP was used as a source of NO. The peppermint (Mentha x piperita L.) seedlings of eight leaves were grown under natural conditions (mean temperature: $20{ }^{\circ} \mathrm{C}, \mathrm{RH}: 32 \%$ ) treated with three different levels of nSe $\left(0,2\right.$, and $\left.20 \mathrm{mg} \mathrm{l}^{-1}\right)$ and/or two levels of NO $\left(0\right.$ and $\left.8 \mathrm{mg} \mathrm{l}^{-1}\right)$. The foliar supplementations with $\mathrm{nSe}$ and/or $\mathrm{NO}$ were done fifteen times with $48 \mathrm{~h}$ intervals. It was equal to $0,0.05$, and 
$0.5 \mathrm{mg} \mathrm{nSe}$ spray $^{-1}$ plant $^{-1}$. Two weeks after the last treatment, the treated plants were harvested for the further studies on the plant growth, anatomy, and physiology. The treatment groups were called as follows: C-control; $\mathrm{NO}$ - nitric oxide of $8 \mathrm{mg} \mathrm{l}^{-1}$; $\mathrm{nSe} 2$ $\mathrm{nSe}$ of $2 \mathrm{mg}^{-1}$; nSe20- nSe of $20 \mathrm{mg} \mathrm{l}^{-1}$; NO $+\mathrm{nSe} 2-$ nitric oxide of $8 \mathrm{mg} \mathrm{l}^{-1}$ and $\mathrm{nSe}$ of $2 \mathrm{mg} \mathrm{l}^{-1}$; $\mathrm{NO}+$ nSe20- nitric oxide and nSe of $20 \mathrm{mg} \mathrm{l}^{-1}$.

\subsection{Growth characteristics and photosynthetic pigments}

Various growth-related characteristics, including total fresh mass of seedlings, leaf area, and leaf length were measured. The photosynthetic pigments were extracted by $80 \%(\mathrm{v} / \mathrm{v})$ acetone as a solvent and determined according to the formula presented by Arnon (1949).

\subsection{Enzyme extraction}

$\mathrm{M}$ phosphate buffer ( $\mathrm{pH}$ of 7.5), containing $0.5 \mathrm{mM}$ $\mathrm{Na}_{2}$-EDTA and $0.5 \mathrm{mM}$ ascorbate was applied as an enzyme extraction buffer. Then, the prepared homogenates were centrifuged at four ${ }^{\circ} \mathrm{C}$ and the supernatants were used as an enzyme extract.

\subsection{Nitrate reductase activity}

The activity of nitrate reductase was measured according to the previously presented method by Sym (1984).

\subsection{Peroxidase activity}

Peroxidase activity was determined based on the method described by Hemeda and Klein (1990). Peroxidase activity was expressed in unit $\mathrm{E} \mathrm{g}^{-1}$ fresh mass.

\subsection{Measurement of phenylalanine ammonia lyase (PAL) activity}

PAL activity was determined according to the method represented by Beaudoin-Eagan and Thrope (1985). The enzyme activity was calculated based on the amount of cinnamate production using the standard curve of cinnamic acid. The enzyme activity was expressed in micromole cinnamate per minute per gram fresh mass $\left(\mu\right.$ mole Cin. $\min ^{-1} \mathrm{~g}^{-1} \mathrm{fm}$ ).

\subsection{Estimation of proline content}

Proline was extracted by sulfa salicylic acid ( $3 \%$ w/v) and measured based on the method represented by Bates et al. (1973). The proline contents were calculated, based on the proline standard curve and expressed in microgram per gram fresh mass $\left(\mu \mathrm{g} \mathrm{g}^{-1} \mathrm{f} \mathrm{m}\right)$.

\subsection{Determination of total soluble phenols}

The soluble phenols were extracted using ethanol solvent of $80 \%(\mathrm{v} / \mathrm{v})$ and holding in boiling water bath for $20 \mathrm{~min}$. Folin Ciocalteu method was applied. Content of total soluble phenols were calculated based on the standard curve of tannic acid as a standard and finally, expressed in milligrams per gram leaf fresh mass ( $\left.\mathrm{mg} \mathrm{g}^{-1} \mathrm{f} \mathrm{m}\right)$.

\subsection{Histological procedure}

Ethanol: glycerol (80: 20) was applied as fixator solution. Cross sections of basal stems were prepared. Handmade cross sections of the basal stems, were stained by carmine and methylene blue, observed with the light microscope and photographed.

\subsection{Statistical Analysis}

Data of three independent replicates was subjected to statistical analyses by SPSS software. Significant mean differences between the groups were determined according to Duncan's multiple range test at the level of $\mathrm{P} \leq 0.05$. 


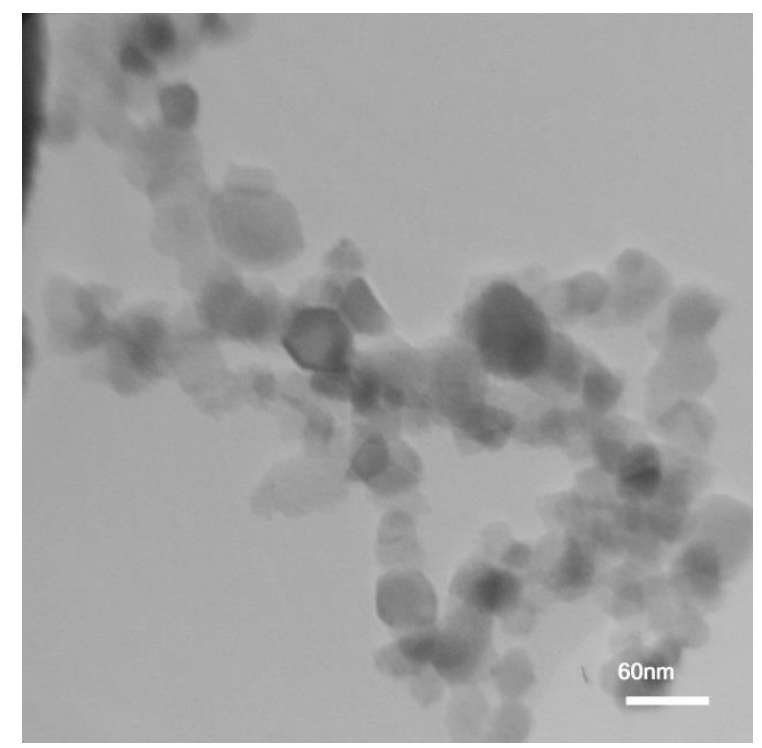

Figure 1: Transmission electron microscope (TEM) image of the spherical nSe.

\section{RESULTS AND DISCUSSION}

\subsection{Growth, biomass, and photosynthetic pigments}

It is interesting to note that leaf length and area were affected by the independent factors of the current research (nSe and NO). The significant rise in the leaf length parameter was enhanced by $7 \%, 16 \%$, and $12 \%$, respectively for the $\mathrm{NO}, \mathrm{nSe}$ of $2 \mathrm{mg} \mathrm{l}^{-1}$, and NO $+\mathrm{nSe} 2$ treatments, relative to the untreated control plants (Figure 2A). However, the nSe of $20 \mathrm{mg} \mathrm{l}^{-1}$ treatment decreased the leaf length about $31 \%$ and $20.8 \%$ for the $\mathrm{nSe}$ of $20 \mathrm{mg} \mathrm{l}^{-1}$ and $\mathrm{NO}+\mathrm{nSe} 20$ treatment groups (Figure 2A). Similarly, the leaf area in the $\mathrm{NO}, \mathrm{nSe}$ of $2 \mathrm{mg} \mathrm{l}^{-1}$ and $\mathrm{NO}+\mathrm{nSe} 2$ treatment groups were found to be significantly $(\mathrm{P} \leq 0.05)$ higher than the control about $15 \%, 38 \%$, and $30 \%$, respectively, whereas the significant reductions in this trait were recorded in the $\mathrm{nSe}$ of $20 \mathrm{mg} \mathrm{l}^{-1}(40 \%)$ and $\mathrm{NO}+\mathrm{nSe} 20(24.7 \%)$ (Figure $2 \mathrm{~B})$. The recorded changes in the leaf characteristics may result from the $\mathrm{nSe}$ and/or NO-induced alterations in the differentiation process of the leaf meristems. NO plays the critical roles in regulating the meristem cell (Sanz et al., 2014). NO is known as a vital reactive nitrogen specie and elicitor of an array of signaling pathways by which regulates the various aspect of plant development and stress responses (Sanz et al., 2014). Moreover, there is evidence that Se may alter the endogenous NO status in plants, mainly in a concentration-dependent manner (Lehotai et al., 2011). Also, the findings clearly indicated that $\mathrm{NO}$ alleviated the toxicity sign of the highest applied dose of $\mathrm{nSe}\left(20 \mathrm{mg} \mathrm{l}^{-1}\right)$, probably via triggering the specific signaling pathways and activating the defense-related system. Shoot fresh masses were significantly $(\mathrm{P} \leq 0.05)$ increased by $26 \%, 30 \%$, and $42 \%$, respectively for $\mathrm{NO}, \mathrm{nSe}$ of $2 \mathrm{mg} \mathrm{l}^{-1}$, and $\mathrm{NO}+$ nSe 2 treatment groups, over the control (Figure 2C). In contrast to the nSe of $2 \mathrm{mg} \mathrm{l}^{-1}$, the nSe of $20 \mathrm{mg} \mathrm{l}^{-1}$ treatment significantly reduced the shoot fresh mass by $33 \%$, relative to the control (Figure 2C). However, this growth-inhibiting impact of the nSe of $20 \mathrm{mg} \mathrm{l}^{-1}$ was mitigated by $\mathrm{NO}$ and the reduction percentage reached to $21.5 \%$ (Figure 2C). In comparison with the control, the applications of the $\mathrm{nSe}$ of $2 \mathrm{mg}^{-1}$ and/or NO treatments, especially the latter factor, significantly $(\mathrm{P} \leq 0.05)$ improved the chlorophyll a (Chla) contents about $24 \%$, whereas nSe of $20 \mathrm{mg} \mathrm{l}^{-1}$ adversely affected this characteristic about $24.8 \%$ and $15.7 \%$ for the nSe of $20 \mathrm{mg} \mathrm{l}^{-1}$ and $\mathrm{NO}+\mathrm{nSe} 20$ groups, respectively (Figure 2D). Interestingly, the adverse impact of nSe of $20 \mathrm{mg} \mathrm{l}^{-1}$ on the Chlb content was mitigated by the applied level of NO, $8 \mathrm{mg} \mathrm{l}^{-1}$, (Figure 2E). Similarly, the applications of the $\mathrm{nSe}$ of $2 \mathrm{mg}^{-1}$ and/or $\mathrm{NO}$ treatments, especially the latter, was significantly $(\mathrm{P} \leq 0.05)$ effective to increase total chlorophyll contents relative to the untreated control (Figure 2F). The $\mathrm{nSe}$ of $20 \mathrm{mg} \mathrm{l}^{-1}$ adversely influenced the total chlorophyll contents about $20 \%$, which was partially relieved by the NO agent and declined to $9.5 \%$ in the $\mathrm{NO}+\mathrm{nSe} 20$-treated plants (Figure $2 \mathrm{~F}$ ). 


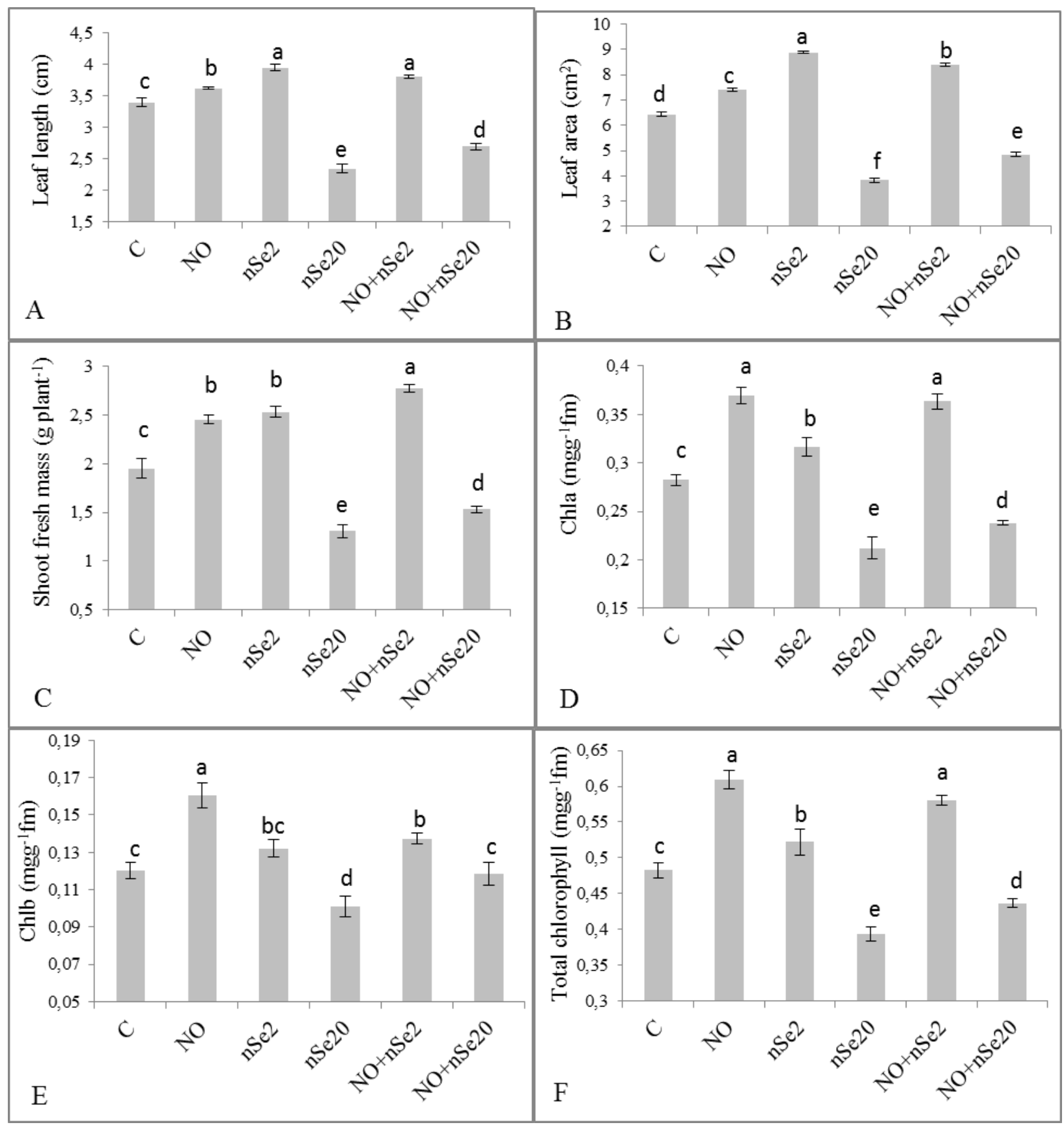

Figure 2: The recorded alterations in different growth-related characteristics and photosynthetic pigments resulted from the foliar applications of peppermint plants with the different concentrations of nSe and/or NO. C-control; NO- nitric oxide of $8 \mathrm{mg}^{-1}$; nSe 2- nSe of $2 \mathrm{mg} \mathrm{l}^{-1}$; nSe 20- $\mathrm{nSe}$ of $20 \mathrm{mg}^{-1}$; $\mathrm{NO}+\mathrm{nSe} 2-\mathrm{NO}$ of $8 \mathrm{mg} \mathrm{l}^{-1}$ and nSe of $2 \mathrm{mg} \mathrm{l}^{-1}$; $\mathrm{NO}+\mathrm{nSe} 20-\mathrm{NO}$ of $8 \mathrm{mg} \mathrm{l}^{-1}$ and nSe of $20 \mathrm{mg} \mathrm{l}^{-1}$.

The modifications in the photosynthetic pigments found in the nSe and/or NO-treated plants could be caused by the possible changes in the nutrition process, redistribution of minerals, and/or the status of antioxidant system. Se-provoked alterations in the different photosynthesis-related characteristics have been reported in the various plant species, like potato
(Germ et al., 2007) and basil (Ardebili et al., 2015). Se toxicity have been attributed to its similarity to sulfur (S), thereby producing nonfunctional proteins and enzymes (Pilon-Smits and Quinn, 2010; Lindblom et al., 2013). The cyto-protective role of NO in the photosynthesis has been attributed to modifying the antioxidant system, stomatal conductance, and interplay 
with $\mathrm{Ca}^{2+}$ signals (Courtois et al., 2008; Velikova et al., 2008). There is evidence that NO may improve the plant responses to stress conditions, mainly via enhancing sulfur assimilation, regulating the synthesis of reduced glutathione (GSH), and modulating the activity of antioxidant enzymes (Fatma et al., 2016). Also, it has been reported that $\mathrm{Se}$ provokes changes in the phytohormones, especially three vital key elicitors of defense signaling-related pathways (salicylic acid, jasmonic acid, and ethylene) (Tamaoki et al., 2008). It is interesting to note that $\mathrm{NO}$ may change the metabolism of auxin (Sanz et al., 2014). A specific and significant cross-talk occurs between NO and other signaling pathways organized by auxin, cytokinin, salicylic acid, jasmonic acid, ethylene, and active oxygen species (Wang et al., 2013). Thus, the above described valuable evidence highlights the significant possible potency of the nSe or NO treatments to change the growth, differentiation, physiology, and/or phytohormonal balances (a critical factor contributes to the relation between the source and sink tissues). Moreover, NOmediated signaling may lead to the modification in assimilation-related processes, thereby dissipating the excess energy and reducing the photo-inhibition process and improving the cellular protection.

\subsection{Nitrate reductase and proline}

The significant inductions in the activities of leaf nitrate reductase were recorded by $80 \%, 42 \%$, and $32 \%$ respectively for the $\mathrm{nSe} 2, \mathrm{NO}+\mathrm{nSe} 2$, and $\mathrm{NO}+\mathrm{nSe} 20$ treatment groups, compared with the control (Figure $3 \mathrm{~A})$. It is interesting to note that; the $\mathrm{nSe}$ of $20 \mathrm{mg} \mathrm{l}^{-1}$ significantly inhibited the activity of the nitrate reductase enzyme by $31 \%$ (Figure 3A). Taking account of the nitrate reductase (a critical enzyme involved in the nitrogen assimilation), the recorded dramatic decrease in the activity of this enzyme in the nSe 20 group, contrasted with the nSe 2 clearly reflected that nSe in a dose and application method dependent manner may lead to the improvement or disturbance in the nitrogen assimilation process. The findings showed that NO mitigated the toxicity signs of the nSe of $20 \mathrm{mg} \mathrm{l}^{-1}$. The induction in the nitrate reductase activity found in the $\mathrm{NO}+\mathrm{nSe} 20$ treatment group may be responsible for mitigating the toxicity sign of the high dose of nSe. Therefore, the nitrate reductase activity may regard as a key mechanism and index contributing to the potential benefits and toxicity of $\mathrm{nSe}$. In agreement with our results, Se fortification stimulated the nitrogen assimilation process, via improving the activities of the nitrate reductase, in potato (Munshi and Mindy, 1992), and wheat (Hajiboland and Sadeghzade, 2014). Also, it has been reported that the $\mathrm{Se}$ fortification altered contents of the leaf nitrate in spinach (Golubkina et al., 2017). Although, there is evidence that Se different salts in a dose and source dependent-ways prevented the nitrate uptake and activity of the nitrate reductase in barley (Hordeum vulgare L.) which was partially alleviated by the sulfate (Aslam et al., 1990). The proline contents in the nSe and/or NO-treated plants were found to be significantly higher than the control, among which the highest amounts were recorded in the $\mathrm{NO}+\mathrm{nSe} 20(43.7 \%)$ and $\mathrm{NO}+\mathrm{nSe} 2(39 \%)$ groups (Figure 3B). The dramatic increase in the proline content as a multifunctional cytoprotective agent may result from the nSe and/or NO applications. The Semediated modification in the amino acid metabolism has been introduced as a critical mechanism by which it may enhance plant resistance to stress condition (Ježek et al., 2011; Ardebili et al., 2015). Moreover, the modification in the nitrogen assimilation and metabolism may be considered as an alternative way to dissipate the excess energy, thereby reducing photoinhibition process and improving cellular protection. 


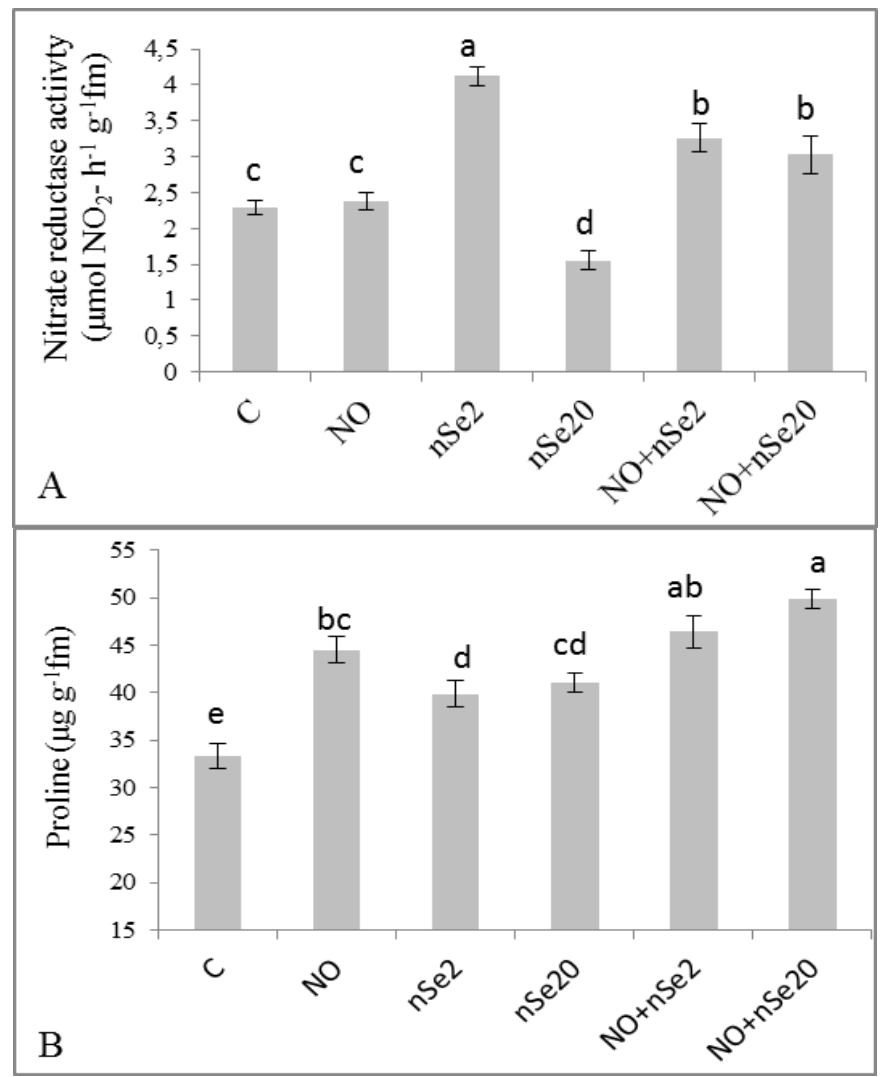

Figure 3: The recorded changes in the activity of nitrate reductase enzyme and proline contents caused by the different concentrations of nSe and/or nitric oxide. C-control; NO- nitric oxide of $8 \mathrm{mg} \mathrm{l}^{-1}$; nSe 2 - $\mathrm{nSe}$ of $2 \mathrm{mg} \mathrm{l}^{-1}$; nSe 20 - nSe of $20 \mathrm{mg} \mathrm{l}^{-1}$; NO + nSe $2-\mathrm{NO}$ of $8 \mathrm{mg} \mathrm{l}^{-1}$ and nSe of $2 \mathrm{mg} \mathrm{l}^{-1} ; \mathrm{NO}+\mathrm{nSe} 20-\mathrm{NO}$ of $8 \mathrm{mg} \mathrm{l}^{-1}$ and nSe of $20 \mathrm{mg} \mathrm{l}^{-1}$

\subsection{Peroxidase, PAL, and soluble phenols}

In comparison to the control, the peroxidase activities were induced by $57 \%, 35 \%, 68 \%$, and $50 \%$ respectively for the $\mathrm{NO}, \mathrm{nSe} 2, \mathrm{NO}+\mathrm{nSe} 2$, and $\mathrm{NO}+$ nSe 20 treatment groups, while this parameter was adversely influenced about $33 \%$, for the individual treatment of the $\mathrm{nSe}$ of $20 \mathrm{mg} \mathrm{l}^{-1}$ (Figure 4A). The alleviated toxicity sign of nSe of $20 \mathrm{mg} \mathrm{l}^{-1}$ by NO may be partially attributed to the dramatic increases in the peroxidase activity, a crucial antioxidant enzyme. In plants, Se- induced antioxidant system has been regarded as a main mechanism contribute to its protective roles against various abiotic stress conditions (Feng et al., 2013; Ardebili et al., 2014; Ardebili et al., 2015).

The foliar supplementations with nSe and/or NO led to the improvement in the activities of PAL enzyme by $68 \%, 28 \%, 45 \%, 47 \%$, and $70 \%$ respectively for the $\mathrm{NO}, \mathrm{nSe} 2, \mathrm{nSe} 20, \mathrm{NO}+\mathrm{nSe} 2$, and $\mathrm{NO}+\mathrm{nSe} 20$ groups, over the untreated control samples (Figure 4B). In addition, except for the NO group (5\%) the other applied treatments had significantly higher amounts of the soluble phenols by $12 \%, 26 \%, 20 \%$, and $20.5 \%$, over the control respectively (Figure 4C). Considering the observed inducing effects of the PAL activity (a key enzyme of phenylpropanoid metabolism) and the soluble phenols by the applied supplements, it seems that these compounds have a considerable potency to affect secondary metabolism, thereby changing the quality and quantity of the secondary metabolites in plants, especially towards medicinal crops. As mentioned above an increase in the salicylic acid, a major phenylpropanoid involved in a plant acclimatization response to various stress factors, has been observed in the Se-treated Arabidopsis (Tamaoki et al., 2008). Also, rise in the phenylalanine content has been reported in the Se-fertilized plant (Munshi et al., 1990; Ježek et al., 2011). The production of the phenylpropanoids, mainly derived from phenylalanine and tyrosine, is triggered as one of the crucial defense mechanisms under a variety of biotic and abiotic stress agents. Therefore, it seems that the possible enhances in the salicylic acid contents may be responsible for the recorded results. 


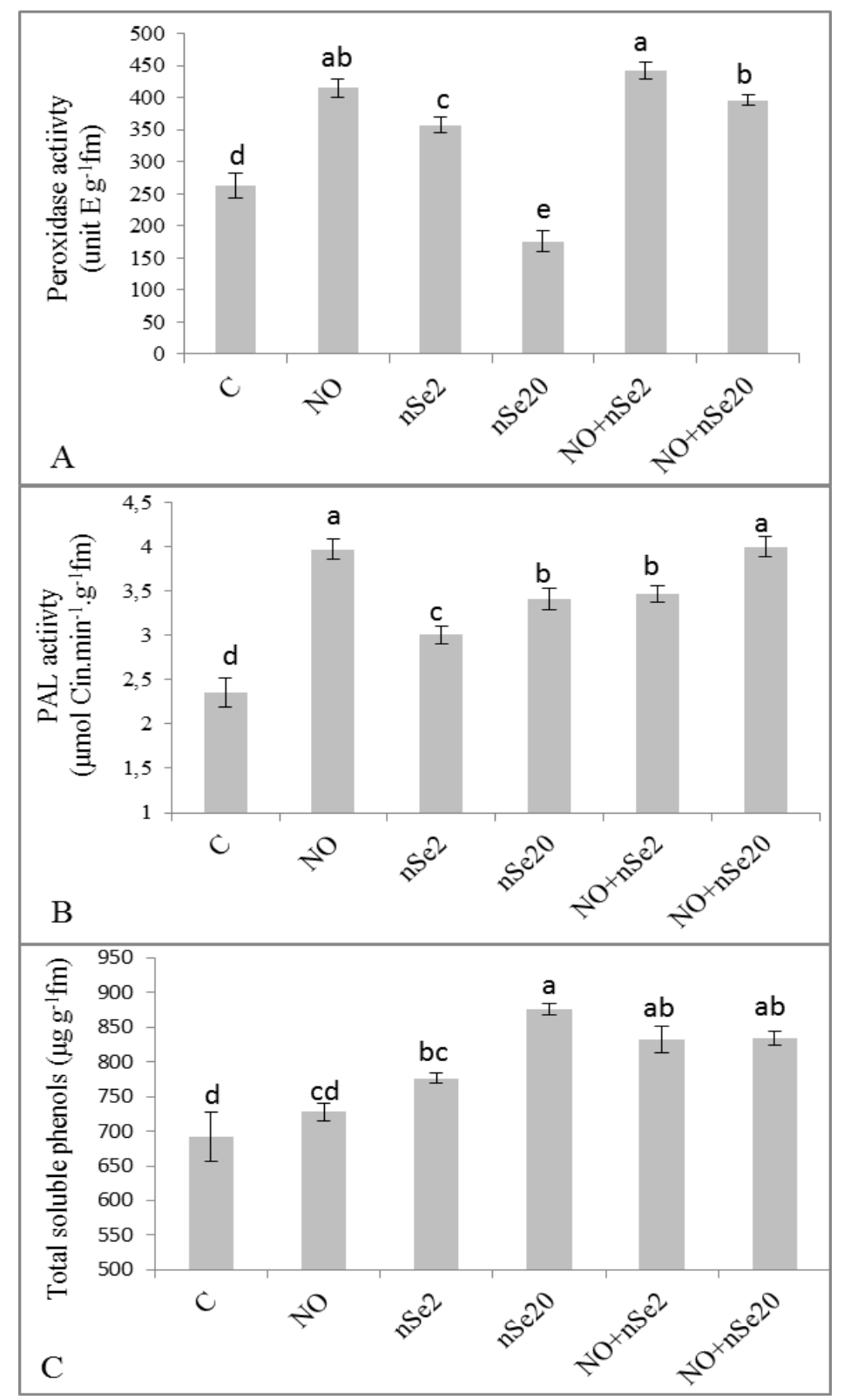

Figure 4: The recorded changes in the activities of peroxidase and PAL enzymes and total soluble phenols induced by the different concentrations of $\mathrm{nSe}$ and/or nitric oxide. C-control; NO- nitric oxide; nSe 2 - $\mathrm{nSe}$ of $2 \mathrm{mg} \mathrm{l}^{-1}$; nSe20- nSe of $20 \mathrm{mg} \mathrm{l}^{-1}$; NO-nSe2- nitric oxide and nSe of $2 \mathrm{mg} \mathrm{l}^{-1}$; NO-nSe20- nitric oxide and nSe of $20 \mathrm{mg} \mathrm{l}^{-1}$.

\subsection{Anatomical evaluation}

In a complementary study, anatomical changes in the $\mathrm{nSe}$ and/or NO-treated plants were evaluated based on the cross-section of the basal stem (Figure 5). As it is presented in Figure 5, the toxicity of nSe $\left(20 \mathrm{mg} \mathrm{l}^{-1}\right)$ treatment led to the severe cell destruction in the cortex layer of the basal stem (Figure 5E). However, the destructive impact of this treatment was partially alleviated by NO (Figure 5F). While, the application of nSe of $2 \mathrm{mg} \mathrm{l}^{-1}$ led to the only slightly destruction in collenchyma tissue (Figure 5C, D). Also, the NO strengthened the collenchyma tissue as it was depicted with the more colorfulness of this tissue in NO-treated plants. The present research provides the anatomical evidence on the toxicity of nSe for the first time on the basis of our knowledge. The found cellular destruction in the cortex layer may result from the ethylene accumulation as a cellular destruction agent, mainly via inducing the activity of hydrolytic enzymes (especially pectinase). Also, salicylic acid in combination with the ethylene may be considered as a triggering factor of the programmed cell death which is partially delayed by NO, the efficient signaling agent. The enhanced rate of 
ethylene synthesis results in the cell death and destruction (Gunawardena et al., 2001). Se provokes alterations in the phytohormones, including salicylic acid, jasmonic acid, and ethylene (Tamaoki et al., 2008), thereby affecting a cellular metabolism and patterns of gene expression. Also, NO may change an auxin metabolism (Sanz et al., 2014). Moreover, Se alters the endogenous NO status in plants (Lehotai et al., 2011). Plant defense system is modulated through the multiple networks of transduction pathways triggered by some critical signaling molecules, especially active oxygen species, NO, salicylic acid, jasmonic acid, and ethylene (Bouchez et al., 2007). Salicylic acid is involved in the induction process of the programmed cell death (Brodersen et al., 2005). Also, it is well known that ethylene may provoke the programmed cell death pathways and influences the activities of the hydrolytic enzymes, especially pectinase. There is evidence depicting NO acted as a protective antioxidant agent and delays the programmed cell death in barley aleurone cells (Beligni et al., 2002). Therefore, the recorded cellular destruction caused by nSe could be attributed to changes in the phytohormonal balances, especially ethylene, where this toxicity sign is partially alleviated by the applied exogenous NO, probably through influencing the hormonal balances and/or triggering the specific defense signaling.

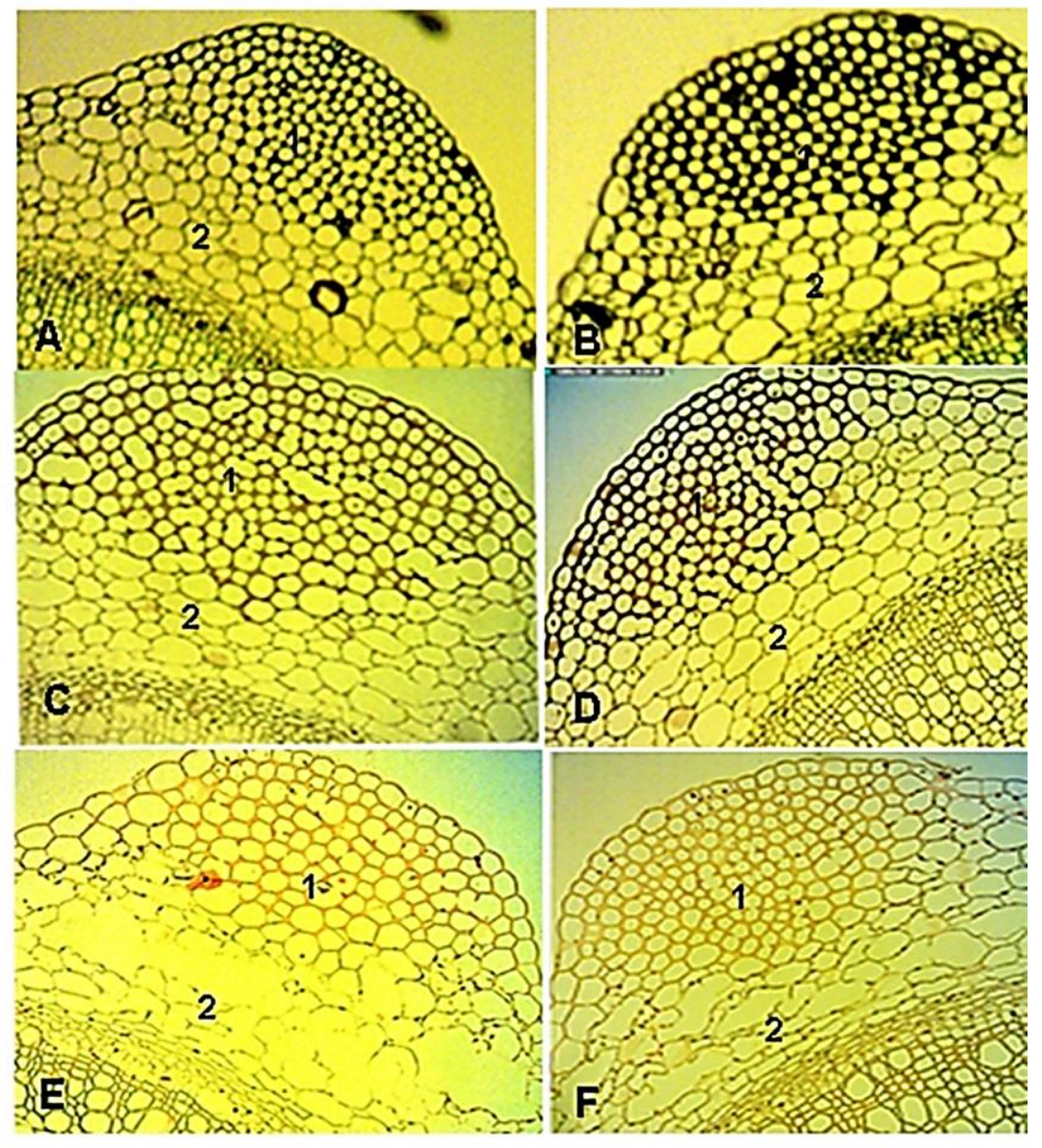

Figure 5: The recorded anatomical changes based on the cross-sections of the basal stem of peppermint plants supplemented by the different concentrations of nSe and/or NO. A-control; B- NO of $8 \mathrm{mg} \mathrm{l}^{-1}$; C- nSe of $2 \mathrm{mg} \mathrm{l}^{-1}$; D- nSe of $2 \mathrm{mg} \mathrm{l}^{-1}$ and NO of $8 \mathrm{mg} \mathrm{l}^{-1}$; E- nSe of $20 \mathrm{mg} \mathrm{l}^{-1}$; F- nSe of $20 \mathrm{mg} \mathrm{l}^{-1}$ and NO of $8 \mathrm{mg} \mathrm{l}^{-1}$. 1 and 2 refer to the collenchyma tissue and cortex layer, respectively

\section{CONCLUSION}

The present study represents the valuable data on the potential benefits and phytotoxicity of nSe and the partially mitigating effects of NO. The obtained results clearly represented that $\mathrm{nSe}$ and/or $\mathrm{NO}$ in a dosedependent manner has a considerable potency to affect the plant growth, anatomy, and metabolism. It seems 
that the simultaneous applications of the suitable concentrations of nSe and NO may be introduced as an alternative strategy to improve the plant growth, metabolism, and protection, taking account of the sustainable agriculture and environmental issues. Also, NO-mediated critical mechanisms, including a higher possible efficiency of photosynthesis, regulating the activities of key enzymes, modifying the nitrogen assimilation, enhancing in the proline content as a multifunctional protecting agent, and controlling the phytohormonal balances may responsible for mitigating the toxicity sign of the high dose of nSe. In addition, the anatomical evidence of the phytotoxicity of the high dose of $\mathrm{nSe}$ and the potential benefits of $\mathrm{NO}$ was provided for the first time. It is obvious that more concise studies are required to justify the exact involved mechanisms (especially at a molecular level).

\section{ACKNOWLEDGMENTS}

Authors would like to thank Dr. Z. Gaziani, Dr. M. Bodaghi, and Dr. S. Zarinkamar for their professional and warming supports. This research was founded by Islamic Azad University, Garmsar branch.

\section{REFERENCES}

Ardebili, N.O., Saadatmand, S., Niknam, V., \& Khavari-Nejad, R. (2014). The alleviating effects of selenium and salicylic acid in salinity exposed soybean. Acta Physiologiae Plantarum, 36, 3199205. doi:10.1007/s11738-014-1686-6

Ardebili, Z. O., Ardebili, N., O., Jalili, S., \& Safiallah, S. (2015). The modified qualities of basil plants by selenium and/or ascorbic acid. Turkish Journal of Botany, 39, 401-407. doi:10.3906/bot-1404-20

Arnon, D.I. (1949). Copper enzymes in isolated chloroplasts. Polyphenoloxidase in Beta vulgaris. Plant physiology, 24(1), 1. doi:10.1104/pp.24.1.1

Asgari-Targhi, G., Iranbakhsh, A., \& Ardebili, Z.O., (2018). Potential benefits and phytotoxicity of bulk and nano-chitosan on the growth, morphogenesis, physiology, and micropropagation of Capsicum annuum. Plant Physiology and Biochemistry, 127, 393-402. doi:10.1016/j.plaphy.2018.04.013

Aslam, M., Harbit, K.B., \& Huffaker, R. (1990). Comparative effects of selenite and selenate on nitrate assimilation in barley seedlings. Plant cell and Environment, 13,773-82. doi:10.1111/j.13653040.1990.tb01093.x

Bates, L., Waldren, R., and Teare, I. (1973). Rapid determination of free proline for water-stress studies. Plant Soil 39, 205-207. doi:10.1007/BF00018060

Beaudoin-Eagan, L.D., \& Thorpe, T. (1985). Tyrosine and phenylalanine ammonia lyase activities during shoot initiation in tobacco callus cultures. Plant Physiology 78, 438-441. doi:10.1104/pp.78.3.438

Beligni, M.V., Fath, A., Bethke, P.C., Lamattina, L. and Jones, R.L. (2002). Nitric oxide acts as an antioxidant and delays programmed cell death in barley aleurone layers. Plant physiology, 129(4), 1642-1650. doi:10.1104/pp.002337

Bouchez, O., Huard, C., Lorrain, S., Roby, D. and Balagué, C. (2007). Ethylene is one of the key elements for cell death and defense response control in the Arabidopsis lesion mimic mutant vad1. Plant physiology, 145(2), 465-477. doi:10.1104/pp.107.106302

Brodersen, P., Malinovsky, F.G., Hématy, K., Newman, M.A. and Mundy, J. (2005). The role of salicylic acid in the induction of cell death in Arabidopsis acd11. Plant Physiology, 138(2), 1037-1045. doi:10.1104/pp.105.059303

Çoban, Ö., \& Baydar, N. G. (2016). Brassinosteroid effects on some physical and biochemical properties and secondary metabolite accumulation in peppermint (Mentha piperita L.) under salt stress. Industrial Crops and Products, 86, 251-258. doi:10.1016/j.indcrop.2016.03.049

Courtois, C., Besson, A., Dahan, J., Bourque, S., Dobrowolska, G., Pugin, A., \& Wendehenne, D. (2008). Nitric oxide signaling in plants: interplays with $\mathrm{Ca}^{2+}$ and protein kinases. Journal of Experimental Botany, 59, 155-63. doi:10.1093/jxb/erm197

El-Ramady, H., Abdalla, N., Taha, H.S., Alshaal, T., ElHenawy, A, Salah, E.D., Shams, M.S., Youssef, S.M., Shalaby, T., Bayoumi, Y., \& Elhawat, N. (2016). Selenium and nano-selenium in plant nutrition. Environmental Chemistry Letters, 14, 2347. doi:10.1007/s10311-015-0535-1

Fatma, M., Masood, A., Per, T.S., \& Khan, N.A. (2016). Nitric oxide alleviates salt stress inhibited photosynthetic performance by interacting with 
sulfur assimilation in mustard. Frontiers in Plant Science ,7. doi:10.3389/fpls.2016.00521

Feng, R., Wei, C., \& Tu, S. (2013). The roles of selenium in protecting plants against abiotic stresses. Environmental and Experimental Botany, 87, 58-68. doi:10.1016/j.envexpbot.2012.09.002

Germ, M., Kreft, I., Stibilj, V., \& Urbanc-Berčič, O. (2007). Combined effects of selenium and drought on photosynthesis and mitochondrial respiration in potato. Plant Physiology and Biochemistry, 45(2), 162-167. doi:10.1016/j.plaphy.2007.01.009

Golubkina, N.A., Kosheleva, O.V., Krivenkov, L. V., Dobrutskaya, H. G., Nadezhkin, S., \& Caruso, G. (2017). Intersexual differences in plant growth, yield, mineral composition and antioxidants of spinach (Spinacia oleracea L.) as affected by selenium form. Scientia Horticulturae, 225, 350358. doi:10.1016/j.scienta.2017.07.001

Gunawardena, A., Pearce, D.M., Jackson, M.B., Hawes, C.R., \& Evans, D.E. (2001). Characterisation of programmed cell death during aerenchyma formation induced by ethylene or hypoxia in roots of maize (Zea mays L.). Planta, 212, 205214. doi:10.1007/s004250000381

Gupta, K.J., Fernie, A.R., Kaiser, W.M., \& Van Dongen, J.T. (2011). On the origins of nitric oxide. Trends in Plant Science, 16,160-8. doi:10.1016/j.tplants.2010.11.007

Hajiboland, R., \& Sadeghzade, N. (2014). Effect of selenium on $\mathrm{CO} 2$ and NO3- assimilation under low and adequate nitrogen supply in wheat (Triticum aestivum L.). Photosynthetica, 52, 501-510. doi:10.1007/s11099-014-0058-1

Hemeda, H. M., \& Klein, B. P. (1990). Effects of naturally occurring antioxidants on peroxidase activity of vegetable extracts. Journal of Food Science, 55, 184-185. doi:10.1111/j.13652621.1990.tb06048.x

Husen, A., \& Siddiqi, K.S. (2014). Plants and microbes assisted selenium nanoparticles: characterization and application. Journal of Nanobiotechnology, 12, 28. doi:10.1186/s12951-014-0028-6

Ježek, P., Hlušek, J., Lošák, T., Jůzl, M., Elzner, P., Kráčmar, S., Buňka. F., \& Martensson, A. (2011). Effect of foliar application of selenium on the content of selected amino acids in potato tubers (Solanum tuberosum L.). Plant Soil and Environment, 57, 315-320. doi:10.17221/57/2011PSE

Kaur, S., \& Nayyar, H. (2015). Selenium fertilization to salt-stressed mungbean (Vigna radiata (L.) Wilczek) plants reduces sodium uptake, improves reproductive function, pod set and seed yield. Scientia Horticulturae, 197, 304-17. doi:10.1016/j.scienta.2015.09.048

Lehotai, N., Petô, A., Erdei, L., \& Kolbert, Z. (2011). The effect of selenium (Se) on development and nitric oxide levels in Arabidopsis thaliana seedlings. Acta Biologica Szegediensis, 55,105-7.

Liu, X., Yang, Y., Deng, X., Li, M., Zhang, W., \& Zhao, Z. (2017). Effects of sulfur and sulfate on selenium uptake and quality of seeds in rapeseed (Brassica napus L.) treated with selenite and selenate. Environmental and Experimental Botany, 135, 13-20. doi:10.1016/j.envexpbot.2016.12.005

Munshi, C.B., \& Mindy, N.I. (1992). Glycoalkaloid and nitrate content of potatoes as affected by method of selenium application. Biol. Trace Element Research, 33, 21-127. doi:10.1007/BF02784000

Mur, L.A., Mandon, J., Persijn, S., Cristescu, S.M., Moshkov, I.E., Novikova, G.V., Hall, M.A., Harren, F.J., Hebelstrup, K.H., \& Gupta, K.J. (2013). Nitric oxide in plants: an assessment of the current state of knowledge. $A O B$ plants, 5. doi:10.1093/aobpla/pls052

Sanz, L., Fernández-Marcos, M., Modrego, A., Lewis, D.R., Muday, G.K., Pollmann, S., Dueñas, M., Santos-Buelga, C., \& Lorenzo, O. (2014). Nitric oxide plays a role in stem cell niche homeostasis through its interaction with auxin. Plant Physiology, 166, 1972-84. doi:10.1104/pp.114.247445

Sym, G.J. (1984). Optimisation of the in-vivo assay conditions for nitrate reductase in barley (Hordeum vulgare L. cv. Igri). Journal of the Science of Food and Agriculture, 35, 725-30. doi:10.1002/jsfa.2740350703

Tamaoki, M., Freeman, J.L., Marquès, L., \& PilonSmits, E.A.H. (2008). New insights into the roles of ethylene and jasmonic acid in the acquisition of selenium resistance in plants. Plant Signaling and Behavior, 3, 865-867. doi:10.4161/psb.3.10.6050

Tripathi, D.K., Mishra, R.K., Singh, S., Singh, S., Vishwakarma, K., Sharma, S., Singh, V.P., Singh, P.K., Prasad, S.M., Dubey, N.K., \& Pandey, A. (2017). Nitric Oxide Ameliorates Zinc Oxide Nanoparticles Phytotoxicity in Wheat Seedlings: Implication of the Ascorbate-Glutathione Cycle. Frontiers in plant science, 8 . doi:10.3389/fpls.2017.00001

Velikova, V., Fares, S., \& F. Loreto. (2008). Isoprene and nitric oxide reduce damages in leaves exposed to oxidative stress. Plant, Cell and Environment, 
Hossein NAZERIEH et al.

31, 1882-94. doi:10.1111/j.13653040.2008.01893.x

Wang, Y., Loake, G.J. \& Chu, C. (2013). Cross-talk of nitric oxide and reactive oxygen species in plant programed cell death. Frontiers in Plant Science, 4, 314. doi:10.3389/fpls.2013.00314

White, P.J., and Broadley, M. (2009). Biofortification of crops with seven mineral elements often lacking in human diets-iron, zinc, copper, calcium, magnesium, selenium and iodine. New Phytologist, 182, 49-84. doi:10.1111/j.1469-8137.2008.02738.x

Zhao, H., Jin, Q., Wang, Y., Chu, L., Li, X., \& Xu, Y. (2016). Effects of nitric oxide on alleviating cadmium stress in Typha angustifolia. Plant Growth Regulation, 78, 243-251. doi:10.1007/s10725-015-0089-z 